Research article

\title{
Effect of vehicular traffic on pollen size and viability of Apocynaceous plant species
}

\author{
Mandeep Kaur and Avinash Kaur Nagpal* \\ Department of Botanical and Environmental Sciences, Guru Nanak Dev University, Amritsar-143005, Punjab, \\ India
}

*Corresponding Author: avnagpal@yahoo.co.in

[Accepted: 04 June 2017]

\begin{abstract}
Vehicular traffic adds up different kinds of contaminants like heavy metals, polyaromatic hydrocarbons, gaseous toxins etc. to the atmosphere. Pollen grains of different plants have been found to be sensitive to these pollutants, which show varied effects on their viability, and size and hence can be used as bioindicators of air pollution. Keeping this in mind, the present work was designed to measure the pollen viability and pollen size of three common roadside plants, namely Alstonia scholaris, Nerium oleander and Tabernaemontana divaricata belonging to Apocynaceae family growing at seven sites of Amritsar city with varying levels of traffic stress. Pollen viability and pollen size were studied using 2, 3, 5-triphenyl tetrazolium chloride (TTC) staining method. The percentage of pollen viability of A. scholaris ranged from $32.45 \%$ to $65.74 \%$, for $N$. oleander it ranged from $30.3 \%$ to $45.11 \%$ and for $T$. divaricata it ranged from $14.31 \%$ to $49.62 \%$. Pollen size ranged from 22.86 to $23.94 \mu \mathrm{m}$ for A. scholaris, 29.58 to $32.17 \mu \mathrm{m}$ for $N$. oleander and 29.83-32.43 $\mu \mathrm{m}$ for $T$. divaricata. Pollen viability was found to be inversely proportional to a load of traffic at a given site whereas no remarkable variation was found in pollen size. For A. scholaris, a significant negative correlation $(\mathrm{r}=-0.762, \mathrm{p} \leq 0.05)$ was observed between pollen viability and traffic load, while for other two species correlation between pollen viability and traffic load was not statistically significant at $\mathrm{p} \leq 0.05$.
\end{abstract}

Keywords: Air pollutants - Indicator - Traffic stress - Pollen viability - Pollen size - TTC.

[Cite as: Kaur M \& Nagpal AK (2017) Effect of vehicular traffic on pollen size and viability of Apocynaceous plant species. Tropical Plant Research 4(2): 235-241]

\section{INTRODUCTION}

Vehicular exhaust adds up huge amounts of soot particles, smoke, poisonous gases $\left(\mathrm{SO}_{2}, \mathrm{NO}_{2}, \mathrm{CO}_{2}\right.$, VOCs etc.), heavy metals and organic molecules on the roads all over the world. All these air pollutants are known to produce adverse effects on the health of plants, animals and humans (Rezaei et al. 2010, Atkinson et al. 2012). Environmental pollution may also play a significant role in increasing pollen allergenicity and hence asthma problems in humans residing at various polluted areas (Majd et al. 2004). Plants growing outdoors are one of the main and primary targets to all types of air pollutants (Shannigrahi et al. 2004). Plants can act as great candidates for reduction of air pollution at a particular place by absorption, deposition, accumulation and detoxification of harmful pollutants (Prajapati \& Tripathi 2008).

Many studies have shown effects of automobile emissions on leaves, stomatal apertures, pollen viability and growth patterns of plants (Iannotti et al. 2000, Verma et al. 2006). One of the major consequences of air pollution is its effect on pollen grain size, shape, exine sculpturing, viability etc. (Iannotti et al. 2000, Duro et al. 2013, Kaur et al. 2016). The mature pollen grains which are released from the flower buds are dry and while absorbing humidity from the ambient air, they also absorb some contaminants which influence their viability hence, plant's reproductive system (Kaur et al. 2016). Due to lipophilic nature of pollen and its exine surface stiffness, gaseous/particulate and organic/non-organic pollutants generally get accumulated inside it and resulting in a decrease in their size and different morphological deformities (Bist et al. 2004). Pollen, being sensitive indicators of air pollution, can provide interesting and useful information about the adverse effects of air pollution on living systems (Gottardini et al. 2004, Noori et al. 2009, Yousefi et al. 2011, Kaur et al. 2016). 
Reproductive success of any plant is mainly dependent on the quantity and quality of pollen grains produced. Contaminants like pesticides, heavy metals, fluorides, etc. can accumulate on the surface of pollen grains and make them active and sensitive bio-indicators of atmospheric pollution (Noori et al. 2009, Yousefi et al. 2011). The literature survey has revealed enormous reports on the impact of air pollution on pollen grains structure and exine properties but very less work is accessible on the use of pollen grains as bioindicators of air pollution.

For assessment of pollen viability and size, different methods such as in vitro germination tests and staining methods are being used. TTC staining method is one of the widely and fast used methods based on dehydrogenase enzymatic reaction in mitochondria of living cells (Firmage \& Dafni 2001, Soares et al. 2013).

Amritsar, a fast growing city of Punjab (India), is witnessing an exponentially increasing number of vehicles on the roads during the last few decades. Myllyvirta \& Dahiya (2015) in their recent report published by WHO reported Amritsar to be $13^{\text {th }}$ out of 20 most polluted Indian cities and it was found that vehicular exhaust adds an annual average of $92 \mu \mathrm{g} . \mathrm{m}^{-3}$ of $\mathrm{PM}_{2.5}$ (Particulate matter) into the atmosphere. Since roadside trees/shrubs are recipients of air pollution; their pollen studies can give an estimate of the biological effects of air pollution (Gottardini et al. 2004). Hence, the aim of the present study was to estimate the effects of traffic stress on pollen size and viability of three species of ornamental plants belonging to family Apocynaceae has widely grown on the roadsides of Amritsar.

\section{MATERIALS AND METHODS}

\section{Area of study}

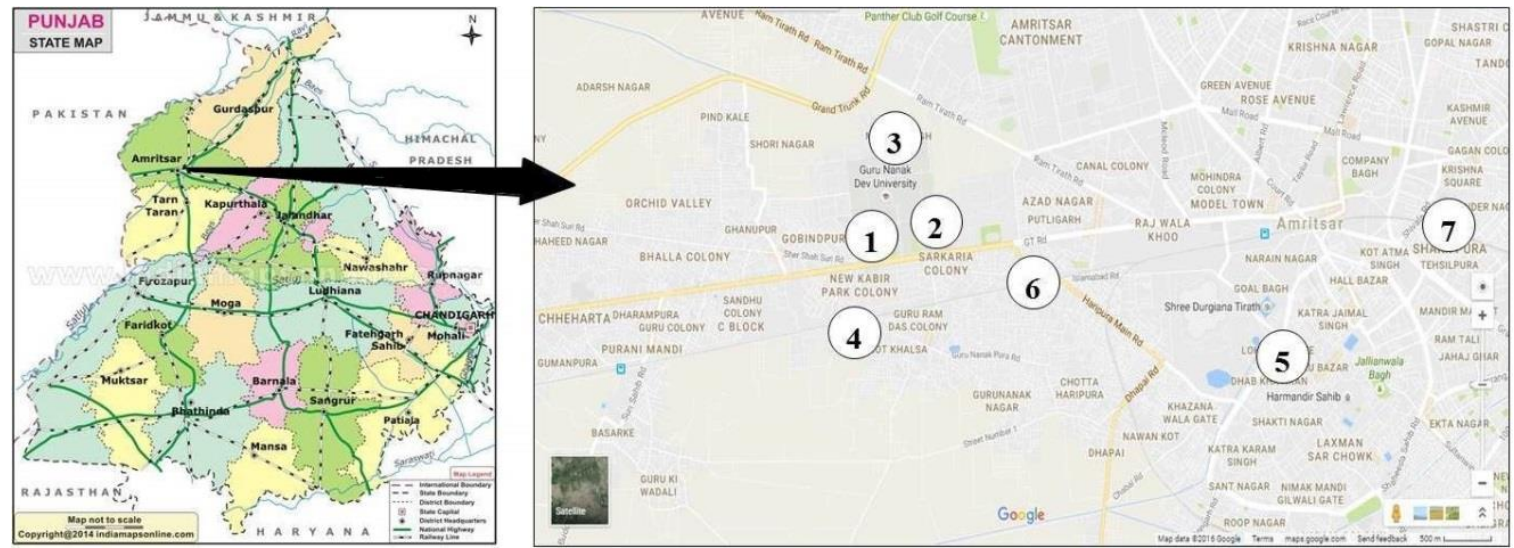

Figure 1. Map showing location of study sites: 1, Botanical Garden, Guru Nanak Dev University (BGG); 2, Khalsa College Campus (KCC); 3, Guru Nanak Dev University Whole Campus (GNC); 4, Kabir Park Colony (KPC); 5, Lahori Gate Road (LGR); 6, Grand Trunk Road (GTR); 7, Ram Bagh Chowk (RBC). [Source: http://www.indmaps.com/state-map/punjab/; https://www.google.co.in/maps/@31.6336711,74.8000795,13z?hl=en]

Table 1. Pollen sampling sites under study.

\begin{tabular}{lll}
\hline S. No. & \multicolumn{1}{c}{ Sampling site with code } & \multicolumn{1}{c}{ Description of site } \\
\hline 1 & Botanical Garden, Guru Nanak Dev & It covers whole area of Botanical Garden of Guru Nanak \\
& University (BGG) & Dev University, Amritsar. \\
2 & Khalsa College Campus (KCC) & It covers whole campus of Khalsa College \\
3 & Guru Nanak Dev University Whole & It covers whole campus of Guru Nanak Dev University \\
& Campus (GNC) & excluding Botanical Garden area \\
4 & Kabir Park Colony (KPC) & Residential colony covering road streets and park areas \\
5 & Lahori Gate Road (LGR) & Road stretch from Beri gate to Lahori Gate \\
6 & Grand Trunk Road (GTR) & Road stretch from Chheharta to Amritsar Railway Station \\
7 & Ram Bagh Chowk (RBC) & It covers area around Ram Bagh Chowk \\
\hline
\end{tabular}

Amritsar, one of the industrialized and rapidly growing cities, is situated at $\mathrm{N} 31.6340^{\circ}, \mathrm{E} 74.8723^{\circ}$ of the Northwestern state (Punjab) of India. The city lies at an average elevation of $234 \mathrm{~m}$ above sea level and covers almost $5075 \mathrm{Km}^{2}$ area. Amritsar has a semiarid climate, with four seasons i.e. winter season (December to March) with minimum temperature of $0^{\circ} \mathrm{C}$ and maximum of about $15^{\circ} \mathrm{C}$; summer season or pre-monsoon (April to June) where temperature can go up to $42^{\circ} \mathrm{C}$; monsoon season from July to September while post-monsoon season is from October to November. Annual rainfall is about 681 millimetres. Its population is about 1,132,761 (Census of India 2011). In the present study, seven roadside sites of Amritsar city were selected (Fig. 1; Table 1). 
Plants under study

Three apocynaceous plant species namely, Alstonia scholaris (L.) R. Br., Nerium oleander L. and Tabernaemontana divaricata (L.) R.Br. ex Roem. \& Schult. growing along the roadsides of Amritsar city, Punjab, India were considered. Brief description of plants under study is presented in table 2. The reason for selection of these plants was their common occurrence at all the studied sites.

Table 2. Description of different plants under study.

\begin{tabular}{|c|c|}
\hline Plant Name & General Features observed \\
\hline $\begin{array}{l}\text { Botanical name- Alstonia scholaris (L.) R. Br. } \\
\text { Common name- Chattiyan/Indian devil tree } \\
\text { Family- Apocynaceae }\end{array}$ & $\begin{array}{l}\text { - Grows up to } 100-130 \mathrm{ft} \text {, flowers bloom in the month of October, } \\
\text { leaves are glossy and occur in whorls of 3-10; petioles are } 1-3 \mathrm{~cm} \text {. } \\
\text { - In Ayurveda, it is an astringent herb for treating skin disorders, } \\
\text { malarial fever, urticaria, chronic dysentery, diarrhea, snake bite } \\
\text { and milk used to treat beriberi disease. }\end{array}$ \\
\hline $\begin{array}{l}\text { Botanical name- Nerium oleander L. } \\
\text { Common name- Kaner/ Oleander } \\
\text { Family- Apocynaceae }\end{array}$ & $\begin{array}{l}\text { - Grows up to } 10-13 \mathrm{ft} \text { in height, leaves are } 10 \text { to } 22 \mathrm{~cm} \text { long. The } \\
\text { plant produces terminal flower heads, usually pink or white. Each } \\
\text { flower is about } 5 \mathrm{~cm} \text { in diameter and five- petalled. } \\
\text { - The whole plant, including the milky white sap, is toxic. The one } \\
\text { of the most studied toxin is oleandrin. }\end{array}$ \\
\hline $\begin{array}{l}\text { Botanical name- Tabernaemontana divaricata (L.) } \\
\text { R.Br. ex Roem. \& Schult. } \\
\text { Common name- Chandni/Crape Jasmine } \\
\text { Family- Apocynaceae }\end{array}$ & $\begin{array}{l}\text { - Grows to a height of } 5 \text { to } 6 \mathrm{ft} \text {, leaves are } 6 \text { inches in length and } 2 \\
\text { inches in width, flowers are pinwheel shaped. } \\
\text { - Root decoction is used in treatment of ascariasis, scabies, internal } \\
\text { poisoning, kidney stones and also used as antipyretic while stems } \\
\text { are used to treat dental caries. }\end{array}$ \\
\hline
\end{tabular}

Collection of buds

Sampling was carried out once in a year, 2014. Flower buds of $N$. oleander and $T$. divaricata were collected during the months of May-July while for A. scholaris sampling for flower buds was done during OctoberNovember. Fresh and young flower buds were collected during early morning hours (5.30-8.30 am) from each species growing at each of the seven sites of Amritsar city. At least 10 flower buds of suitable size were collected from each plant. For each site of the study, buds from three plants of each species were collected. Experiments were carried out in triplicates.

\section{Traffic load}

The traffic load was calculated by counting the number of vehicles including heavy vehicles, four wheelers, three wheelers and 2 wheelers moving at each site for $3 \mathrm{~h}$ at different intervals of time (8-9 am; $12-1 \mathrm{pm} ; 4-5$ pm) with the help of a hand-held counter.

\section{Pollen viability}

Pollen viability was estimated by employing 2, 3, 5-triphenyl tetrazolium chloride (TTC) staining method according to the protocol of Iannotti et al. (2000) with slight modifications. Freshly prepared TTC stain kept in dark bottles was used for making slides every time. TTC stain was prepared by taking $1 \%$ solution of TTC in $60 \%$ sucrose solution. A minimum of 10 anthers from at least 5-8 flower buds of suitable size of each plant were excised with a sharp needle and placed on a slide. Further, a drop of TTC stain was added to squash anthers on the glass slide. A cover slip was placed on the squashed material and air bubbles were removed. The slides were sealed with dibutylphathalate xylene (DPX) and incubated for 2 hrs in daylight. Pollen grains slides were prepared in the field or in laboratory immediately after sampling. The stained slides were then preserved in air tight box. After one day, slides were observed under a light microscope at 400X magnification at room temperature for viable and non-viable pollen grains. Pollen viability was calculated by counting viable and nonviable pollen grains. The deep pink or red stained pollen grains with round shape were counted as viable while white or yellowish pollen grains with shriveled structure were counted as non-viable. A minimum of 1000 pollen grains were studied for each plant. The experiment was carried out in triplicates.

\section{Calculations}

Pollen viability was calculated as,

$$
\text { Pollen viability }(\%)=\frac{\text { Number of viable pollen grains }}{\text { Total number of counted pollen grains }} \times 100
$$




\section{Pollen size}

Light microscope fitted with an ocular micrometer was used to study the size of pollen grains under the magnification of $400 \mathrm{X}$. Ocular micrometer was calibrated by using stage micrometer. At least10 pollen grains were observed for each plant species on average and the studies were carried out in triplicates.

\section{Statistical analysis}

Data was analysed by using the self-coded software on Microsoft Excel 2007 for one-way ANOVA test to compare differences among the studied variables. Tukey's Honestly Significant Difference test (Tukey's HSD) was also performed for multiple comparisons between the means. Correlations between the parameters were also evaluated by calculating the Pearson's correlation coefficient (r).

\section{RESULTS}

In the present study, an attempt was made to assess the effect of traffic load on pollen of three plant species growing at seven sites of Amritsar city under different levels of traffic. Results for traffic load, pollen viability and pollen size are presented in tables 3 . Table 3 depicted varying levels of traffic for each site under study. The highest number of vehicles was observed at the site RBC whereas the lowest number was observed at site KCC. Though vehicles are not allowed inside Botanical Garden of Guru Nanak Dev University (BGG); however, it is adjacent to GT Road, NH 1 (Table 3).

The percentage of pollen viability for Alstonia scholaris ranged from $32.45 \%$ (GTR) to $65.74 \%$ (GNC), for Nerium oleander $30.3 \%$ (LGR) to $45.11 \%$ (KCC) and for Tabernaemontana divaricata $14.31 \%$ (RBC) to $49.62 \%$ (KPC). Pollen viability was found to be inversely proportional to the number of vehicles at a given site. Figure 2 shows viable and non-viable pollen grains of A. scholaris, N. oleander and T. divaricata plant species. Pollen size of $A$. scholaris was observed to range from $22.86 \mu \mathrm{m}$ (GNC) to $23.94 \mu \mathrm{m}$ (GTR), for $N$. oleander $29.58 \mu \mathrm{m}$ (GTR) to $32.17 \mu \mathrm{m}$ (RBC) and for T. divaricata it ranged from $29.83 \mu \mathrm{m}$ (RBC) to $32.43 \mu \mathrm{m}$ (KPC).

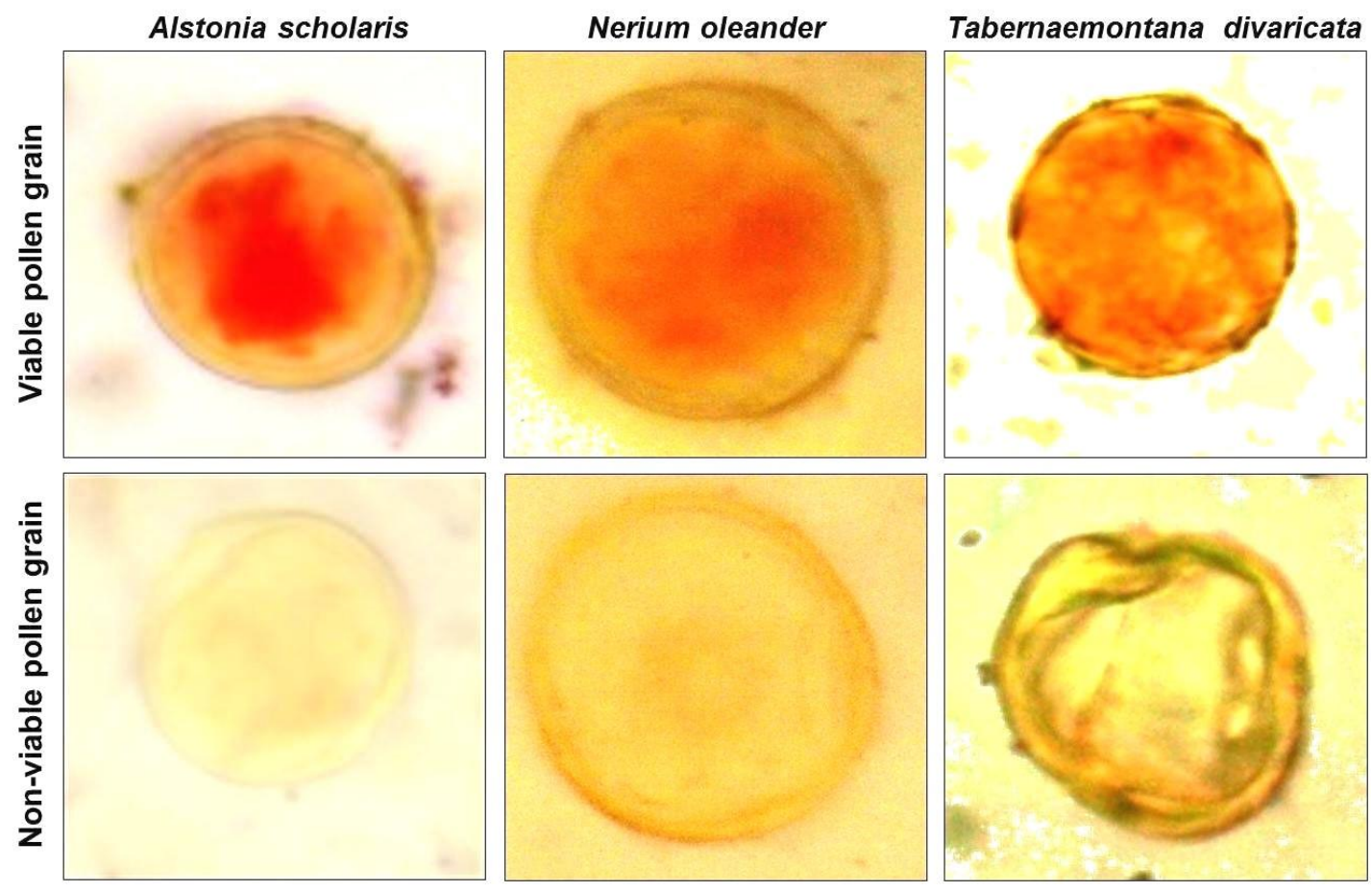

Figure 2. Viable and non-viable pollen grains of the plant species studied.

One way ANOVA test was used to compare the differences between the parameters observed for different plant species growing at different sites of samples collection. ANOVA for pollen viability showed the statistical significant difference with respect to their sites of samples collection whereas no statistically significant variation was observed in pollen size with respect to different sites studied (Table 3). Tukey's HSD test was also used to check the differences in pollen viability and pollen size at different sites studied.

Pearson correlation coefficient ( $r$ ) was calculated to find out the correlation of pollen viability with traffic load and pollen size with traffic load at $\mathrm{p} \leq 0.05$ level of significance (Table 3 ). In the case of A. scholaris, a significant negative correlation between pollen viability and traffic load at different sites was observed $(\mathrm{r}=$ - 
$0.762, \mathrm{p} \leq 0.05)$, while other two species did not show any significant correlation. Pollen size did not show any significant correlation with traffic density for all studied species.

Table 3. Pollen viability and pollen size of Alstonia scholaris, Nerium oleander and Tabernaemontana divaricata growing at the studied sites.

\begin{tabular}{|c|c|c|c|c|c|c|c|c|}
\hline \multirow{2}{*}{$\begin{array}{l}\text { Site } \\
\text { No. }\end{array}$} & \multirow{2}{*}{$\begin{array}{l}\text { Site } \\
\text { code }\end{array}$} & \multirow{2}{*}{$\begin{array}{l}\text { No. of } \\
\text { vehicles }\end{array}$} & \multicolumn{3}{|c|}{ Pollen viability $(\%)($ Mean \pm S.E. $)$} & \multicolumn{3}{|c|}{ Pollen size $(\mu \mathrm{m})($ Mean \pm S.E. $)$} \\
\hline & & & A. scholaris & N. oleander & T. divaricata & A. scholaris & N. oleander & T. divaricata \\
\hline 1. & BGG & 0 & $61.97 \pm 2.916^{\mathrm{a}}$ & $44.36 \pm 1.503^{\mathrm{ab}}$ & $42.59 \pm 2.716^{\mathrm{a}}$ & $23.56 \pm 0.19^{\mathrm{ns}}$ & $31.6 \pm 0.253^{\mathrm{ns}}$ & $31.6 \pm 1.647^{\mathrm{ns}}$ \\
\hline 2. & $\mathrm{KCC}$ & 1891 & $51.39 \pm 5.175^{\mathrm{a}}$ & $45.11 \pm 1.241^{\mathrm{a}}$ & $28.18 \pm 2.668^{\mathrm{b}}$ & $23.31 \pm 0.228^{\mathrm{ns}}$ & $30.34 \pm 0.063^{\mathrm{ns}}$ & $30.72 \pm 0.228^{\mathrm{ns}}$ \\
\hline 3. & GNC & 1989 & $65.74 \pm 3.164^{\mathrm{a}}$ & $33.15 \pm 3.879^{\mathrm{ab}}$ & $26.75 \pm 1.076^{\mathrm{b}}$ & $22.86 \pm 0.88^{\mathrm{ns}}$ & $31.1 \pm 0.708^{\mathrm{ns}}$ & $31.79 \pm 0.522^{\mathrm{ns}}$ \\
\hline 4. & KPC & 2071 & $65.51 \pm 2.855^{\mathrm{a}}$ & $32.48 \pm 3.75^{\mathrm{ab}}$ & $49.62 \pm 0.743^{\mathrm{a}}$ & $23.5 \pm 0.983^{\mathrm{ns}}$ & $31.98 \pm 0.887^{\mathrm{ns}}$ & $32.43 \pm 1.082^{\mathrm{ns}}$ \\
\hline 5. & LGR & 2563 & $33.8 \pm 2.096^{\mathrm{b}}$ & $30.3 \pm 4.836^{\mathrm{b}}$ & $16.47 \pm 0.598^{c}$ & $23.69 \pm 0.127^{\mathrm{ns}}$ & $31.22 \pm 0.253^{\mathrm{ns}}$ & $30.84 \pm 1.513^{\mathrm{ns}}$ \\
\hline 6. & GTR & 3923 & $32.45 \pm 2.44^{\mathrm{b}}$ & $37.61 \pm 2.448^{\mathrm{ab}}$ & $27.60 \pm 1.152^{\mathrm{b}}$ & $23.94 \pm 0.396^{\mathrm{ns}}$ & $29.58 \pm 0.933^{\mathrm{ns}}$ & $32.17 \pm 1.104^{\mathrm{ns}}$ \\
\hline 7. & RBR & 4551 & $32.59 \pm 1.068^{\mathrm{b}}$ & $32.47 \pm 1.775^{\mathrm{ab}}$ & $14.31 \pm 1.455^{\mathrm{c}}$ & $23.37 \pm 0.396^{\mathrm{ns}}$ & $32.17 \pm 0.887^{\mathrm{ns}}$ & $29.83 \pm 0.190^{\mathrm{ns}}$ \\
\hline \multicolumn{3}{|c|}{ F-value } & $27.00 *$ & $3.71 * *$ & $56.73 *$ & $0.37^{\text {ns }}$ & $0.28^{\text {ns }}$ & $0.76^{\text {ns }}$ \\
\hline \multicolumn{3}{|c|}{ HSD } & 14.70 & 14.75 & 8.23 & - & - & - \\
\hline \multicolumn{3}{|c|}{$\begin{array}{l}\text { Pearson's correlation } \\
\text { coefficient }(\mathbf{r})\end{array}$} & $-0.762 * * *$ & $-0.529^{n s}$ & $-0.645^{n s}$ & $0.213^{\mathrm{ns}}$ & $0.134^{\text {ns }}$ & $-0.356^{n s}$ \\
\hline
\end{tabular}

Note: BGG- Botanical Garden, Guru Nanak Dev University; KCC- Khalsa College Campus; GNC- Guru Nanak Dev University Whole Campus; KPC- Kabir Park Colony; LGR- Lahori Gate Road; GTR- Grand Trunk Road; RBR- Ram Bagh Chowk. ${ }^{\circledR}$ Total number of vehicles counted at each site for $3 \mathrm{hrs}$ at different intervals of time i.e. $8-9 \mathrm{am} ; 12-1 \mathrm{pm} ; 4-5 \mathrm{pm}$.

Means with same superscript showed no significant difference at $\mathrm{p} \leq 0.05$ between sites using Tukey's Multiple Comparison Test.

*Data is statistically significant at $\mathrm{p} \leq 0.001$; **Data is statistically significant at $\mathrm{p} \leq 0.05$; ***values show significant correlation between traffic load and pollen viability/pollen size at $\mathrm{p} \leq 0.05$ level of significance; ${ }^{\text {ns }}$ values are not significant at $\mathrm{p} \leq 0.05$ level of significance.

\section{DISCUSSION}

Automobile generated air pollutants and different environmental stresses have played a major role in influencing the pollen viability and pollen size of different plant species (Gottardini et al. 2004, Higashitani 2013, Rezanejad 2013, Paupière et al. 2014).

The viability of pollen grains of plants under study was determined by TTC staining method which works on the colouring of tissue. TTC gets reduced by the dehydrogenase enzyme of live tissues and results information of a carmine red colour compound known as formazan (Beyhan \& Serdar 2008). This method is relatively simple and gives rapid results (Soares et al. 2013). This technique has been commonly used for studying the effects of automobile generated airborne pollutants including heavy metals on viability/fertility of pollen grains of several plant species (Duro et al. 2013). The results obtained by this method are well comparable to those obtained by in vitro germination tests (Huang et al. 2004). Many studies have suggested the use of TTC as a reliable method for assessment of pollen viability (Iannotti et al. 2000, Gottardini et al. 2004, Huang et al. 2004, Abdelgadir et al. 2012, Kaur et al. 2016). Staining techniques used for estimation of pollen viability and size of pollen grains depend on the type of plant species. These stains/dyes can easily point out differentiation among viable and non-viable pollen grains (Kolodziejek \& Gabara 2008, Sharafi 2011).

In the present study, as a result of vehicular emissions, remarkable effects on pollen viability of three plant species under study were observed. Viable pollen grains were found to be darkly stained and round in shape while non-viable pollen grains were found to be transparent and have shriveled structure. Pollen viability of plant species studied was found to be negatively correlated with the traffic load (no. of vehicles) of different sites where these plants were growing. Effects of air pollutants on pollen viability and size have been well documented for different plant species (Chauhan \& Singh 1996, Malayeri et al. 2012, Greguskova \& Micieta 2013). Dickinson (2000) and Rezanejad (2009) observed alterations in proteins involved in pollen-stigma interactions as a consequence of automobiles generated air pollution.

Pollen size of Alstonia scholaris, Nerium oleander and Tabernaemontana divaricata at all sites was found to be unaffected irrespective of high vehicle number. One way ANOVA test showed no significant differences between pollen grains size from different sites of sample collection whereas pollen viability of A. scholaris $(\mathrm{p} \leq 0.001), T$. divaricata $(\mathrm{p} \leq 0.001)$ and $N$. oleander $(\mathrm{p} \leq 0.05)$ showed statistically significant differences with respect to their sites of sample collection. Our results are in conformity with some of the earlier studies on different plant species like Daucus carota L., Convolvulus sepium L. and Dactylis glomerata L. (Iannotti et al. 2000); Cassia fistula L., Cannabis sativa L. and Thevetia peruviana (Pers.) K. Schum. (Kaur et al. 2016).

Pearson's Correlation Coefficient analysis suggests that among the three species studied, Alstonia scholaris $(\mathrm{r}=-0.762$, at $\mathrm{p} \leq 0.05)$ was found to be most sensitive to air pollution followed by Tabernaemontana divaricata www.tropicalplantresearch.com 
$(\mathrm{r}=-0.645)$; Nerium oleander ( $\mathrm{r}=-0.529)$ was relatively tolerant to traffic stress (Table 3). Hence, Alstonia scholaris and Tabernaemontana divaricata can be used as better bio-indicators of vehicular air pollution whereas $N$. oleander can be the plant of choice for polluted sites. Earlier also it was reported that pollen viability can be used as reliable bio-indicator of atmospheric pollution (Iannotti et al. 2000, Greguskova \& Micieta 2013). Malayeri et al. (2012) reported the use of pollen viability and morphology of six legumes viz., Cercis siliquastrum L., Medicago sativa L., Robinia pseudoacacia L., Melilotus officinalis (L.) lam, Trifolium repens L., and Sophoraalo pecuroides L. for bio-monitoring of fluoride generated pollution.

\section{CONCLUSION}

The present study showed that pollen viability relatively decreases with increase in vehicle number while pollen size did not show any significant variation. On the basis of pollen viability data, $N$. oleander was found to be tolerant to air pollution while A. scholaris was found to be highly sensitive followed by Tabernaemontana divaricata, hence, the latter two can act as better indicators of air pollution with respect to traffic stress. Present work provides information for three species only, which is insufficient to draw a specific conclusion. The effect on pollen viability and pollen size depends on the type of plant species and level of traffic stress. It can be concluded that pollen grains can give important information about the biological impact of air pollutants and can be used as good candidates as bio-indicators of the atmospheric pollution. This kind of work may be helpful in exploration of tolerance or sensitivity level of different roadside plant species against air pollution.

\section{ACKNOWLEDGEMENTS}

Thanks are due to University Grants Commission (UGC) for financial assistance under CPEPA, UPE and DRS programes. Mandeep Kaur is recipient of UGC-BSR fellowship. Authors also thank Prof. A. K. Thukral, Department of Botanical \& Environmental Sciences, GNDU for designing self coded software in MS Excel 2007 for statistical analysis of the data.

\section{REFERENCES}

Abdelgadir HA, Johnson SD \& VanStaden J (2012) Pollen viability, pollen germination and pollen tube growth in the biofuel seed crop Jatropha curcas (Euphorbiaceae). South African Journal of Botany 79: 132-139.

Atkinson RW, Yu D, Armstrong BG, Pattenden S, Wilkinson P, Doherty RM, Heal MR \& Anderson HR (2012) Concentration-Response function for Ozone and daily mortality: Results from five urban and five rural U.K. populations. Environmental Health Perspectives 120 (10): 1411-1417.

Beyhan N \& Serdar U (2008) Assessment of pollen viability and germinability in some European chestnut genotypes (Castanea sativa L.). Horticultural Science (Prague) 35(4): 171-178.

Bist A, Pandit T, Bhatnagar AK \& Singh AB (2004) Variability in protein content of pollen of Castor bean (Ricinus communis) before and after exposure to the air pollutants $\mathrm{SO}_{2}$ and $\mathrm{NO}_{2}$. Grana 43: 94-100.

Chauhan SVS \& Singh J (1996) Deterioration of pollen fertility in response to air pollution: A review. In: Agrawal SK, Tiwari S \& Dubey PS (eds) Biodiversity and Environment. APH Publ. Co, New Delhi, pp. 197-205.

Dickinson HG (2000) Pollen stigma interactions: So near yet so. Trends in Genetics 16: 373-376.

Duro A, Piccione V \& Zampino D (2013) Air quality biomonitoring through pollen viability of Fabaceae. Environmental Monitoringand Assessment 185: 3803-3817.

Firmage DH \& Dafni A (2001) Field tests for pollen viability; a comparative approach. Acta Horticulturae 561: 87-94.

Gottardini E, Cristofolini F, Paoletti E, Lazzeri P \& Pepponi G (2004) Pollen viability for air pollution biomonitoring. Journal of Atmospheric Chemistry 49: 149-159.

Greguskova E \& Micieta K (2013) Phytoindication of the ecogenotoxic effects of vehicle emissions using pollen abortion test with native flora. Polish Journal of Environmental Studies 22 (4): 1069-1076.

Higashitani A (2013) High temperature injury and auxin biosynthesis in microsporogenesis. Frontier of Plant Sciences 4: 1-4.

Huang Z, Zhu J, Mu X \& Lin J (2004) Pollen dispersion, pollen viability and pistil receptivity in Leymus chinensis. Annals of Botany 93: 295-301.

Iannotti O, Mincigrucci G, Bricchi E \& Frenguelli G (2000) Pollen viability as a bio- indicator of air quality. Aerobiologia 16: 361-365. 
Kaur M, Sharma A, Kaur R, Katnoria JK \& Nagpal AK (2016) Palynological studies of some roadside plants under exposure to traffic stress. Aerobiologia 32 (2): 245-254.

Kolodziejek J \& Gabara B (2008) Palynological study of Polish taxa of Potentilla subsect. Collinae (Rosaceae). ActaBotanica Croaia 67 (2): 139-146.

Majd A, Chehregani A, Moin M, Gholami M, Kohno S, Nabe T \& Shariatzade MA (2004) The effect of air pollution on structures proteins and allergenicity of pollen grains. Aerobiologia 20: 111-118.

Malayeri BE, Noori M \& Jafari M (2012) Using the pollen viability and morphology for fluoride pollution biomonitoring. Biology and Trace Element Research 147: 315-319.

Myllyvirta L \& Dahiya S (2015) A status assessment of National Air Quality Index (NAQI) and pollution level assessment for Indian cities. A report by WHO. Published by Greenpeace, India, pp. 1-19.

Noori M, Malayeri BE \& Jafari M (2009) Determination of fluoride and its effects on flavonoids in some legumes. Toxicology and Environmental Chemistry 91 (3): 409-418.

Paupière MJ, van Heusden AW \& Bovy AG (2014) The metabolic basis of pollen thermo-tolerance: Perspectives for Breeding. Metabolites 4: 889-920.

Prajapati SK \& Tripathi BD (2008) Seasonal variation of leaf dust accumulation and pigment content in plant species exposed to urban particulates pollution. Journal of Environmental Quality 37: 865-870.

Census of India (2011) Cities having population 1 lakh and above. In: Provisional Population Totals. Office of the Registrar General \& Census Commissioner, India. Available from: http://www.censusindia.gov.in/pca/ SearchDetails.aspx?Id=42494 (accessed: 01 Oct. 2016).

Rezaei M, Arzani A \& Sayed-Tabatabaei BE (2010) Meiotic behavior of tetraploidwheats (Triticum turgidum L.) and their synthetic hexaploid wheat derivates influenced by meiotic restitution and heat stress. Journal of Genetics 89: 401-407.

Rezanejad F (2009) Air pollution effects on structure, proteins and flavonoids in pollen grains of Thuja orientalis L. (Cupressaceae). Grana 48 (3): 205-213.

Rezanejad F (2013) The response of anther and pollen development, pollen cellular material release and pollen proteins to air pollution in Petunia hybrid Juss. (Solanaceae). Iranian Journal of Science and Technology, Transaction A: Science 1: 63-68.

Shannigrahi AS, Fukushima T \& Sharma RC (2004) Anticipated air pollution tolerance of some plant species considered for green belt development in and around an industrial/urban area in India: an overview. International Journal of Environmental Studies 61 (2): 125-137.

Sharafi Y (2011) An investigation on the pollen germination and tube growth in some Prunus persica genotypes and cultivars. African Journal of Microbiology Research 5 (14): 2003-2007.

Soares TL, de Jesus ON, de Souza EH, dos Santos-Serejo JA \& de Oliveira EJ (2013) Morphology and viability of pollen grains from passion fruit species (Passiflora spp.). Acta Botanica Brasilica 27(4): 779-787.

Verma RB, Mahmooduzzafar, Siddiqi TO \& Iqbal M (2006) Foliar response of Ipomea pestigridis L. to coal smoke pollution. Turkish Journal of Botany 30: 423-417.

Yousefi N, Chehregani A, Malayeri BE, Lorestani B \& Cheraghi M (2011) Investigating the effect of heavy metals on developmental stages of anther and pollen in Chenopodium botrys L. (Chenopodiaceae). Biologyand Trace Element Research 140: 368-376. 